\title{
Relationship between CD14 and IgA Levels with the Early Childhood Caries Event Children Age 3-5 Years
}

\author{
Deli Mona $^{1 *}$, Gusti Revilla ${ }^{2}$, Yanwirasti Yanwirasti ${ }^{2}$, Nila Kusuma ${ }^{1}$ \\ ${ }^{1}$ Department of Biomedics, Faculty of Dentistry, Andalas University, Padang, Indonesia; ${ }^{2}$ Department of Anatomy, Faculty of \\ Medicine, Andalas University, Padang, Indonesia
}

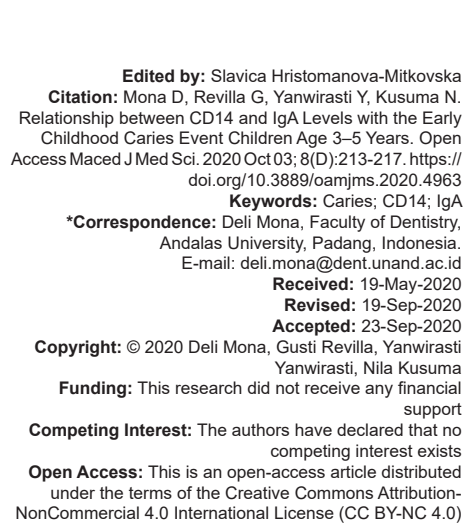

\section{Introduction}

Early childhood caries (ECC) is a problem in the field of dental health that occurs in infants and toddlers around the world [1]. The negative impact of caries on children can be functional changes such as chewing and speaking disorders, psychological disorders such as irritability, disruption of learning processes, and disruption of children's social interactions due to restraint when smiling and talking [2]. This also disrupts the child's growth and development because the incidence of this disease is also increasing from year to year and continues to develop into a pandemic throughout the world [1], [3], [4].

The prevalence of ECC in developing countries such as in the Khartoum City of Sudan in children aged $3-5$ years is $52.4 \%$ [5]. The prevalence of ECC in children aged 3-5 years in the city of Bengaluru, India, is $24.39 \%$ [6]. Developed countries such as England, Hong Kong, Qatar, and Germany have an ECC prevalence of $27.9 \%, 55 \%, 89.2 \%$, and $10 \%$ [7], [8].

Riskesdas in 2013 reported $10.4 \%$ of children aged 1-4 years experienced dental and mouth problems, but only $25.8 \%$ received treatment [9]. The prevalence of ECC in children under 3 years old in DKI Jakarta was $52.7 \%$ with a deft score (decay extraction filling - teeth) average 2.85 [10]. The prevalence of caries in children aged 2-5 years in the city of Yogyakarta, Indonesia, reaches $76.5 \%$ [11]. Dental caries is an infectious disease caused by interactions between bacteria, such as Streptococcus mutans, Actinomyces sp., and Lactobacillus sp. with food in tooth enamel [1]. S. mutans is the main bacterium found in ECC children and plays an important role in caries development [12].

The American Academy of Pediatric Dentistry in 2014 stated that the frequency of consuming liquids containing fermented carbohydrates such as juice, milk, and soda can increase the risk of caries [13]. Bottled milk consumption at night is the most powerful ECC risk factor. The use of bottle milk at night increases the risk of caries because the rate of salivary flow decreases during sleep, which causes the cleaning of the oral cavity by saliva also is low [14].

Saliva has a variety of biomolecules, especially proteins that affect the survival of oral microorganisms through innate defensive mechanisms that modulate oral microflora [15]. More than 1400 salivary proteins have been identified, some of which are immunoglobulins, acidic proline-rich proteins, mucins 1 e 2 (mucous glycoproteins) agglutinin, lactoferrin, and lysozyme, cystatin S, and statherin, defensin, 
CD14, glucosyltransferase, and amylase. The protein along with the glycoprotein contained in saliva protects oral tissue. Changes in salivary protein can result in changes in flora in the oral cavity that can lead to caries formation [16]. The absence of CD14 in saliva can be a potential biomarker of caries [17].

Salivary protein which also acts as the immune system in the oral cavity is immunoglobulin [15]. There are three subclasses of immunoglobulins found in saliva, namely, $\lg \mathrm{A}$, $\lg \mathrm{G}$, and $\lg \mathrm{M}$. IgA is the most common immunoglobulin in saliva (about 60\%) [18]. The salivary secretory immunoglobulin $A$ (slgA) can bind specifically to the epitope of $S$. mutans section, so bacteria cannot bind to the salivary pellicle and S. mutans will not colonize the salivary tooth surface [15]. There is a significant relationship between the amount of $\lg A$ and the incidence of caries in children [18]. The high concentration of slgA in children with ECC is associated with increased antigen exposure, thereby triggering high antibody production [15].

Based on this background, this study focused on one of the main factors in the caries process, namely, the host factor by analyzing the levels of sCD14 and slgA saliva in the population of children with ECC as an effort to develop indicators of prediction of caries in children aged 3-5 years who have the habit of drinking bottled milk.

\section{Materials and Method}

\section{Samples}

This type of research is an observational cross-sectional comparative design between children with caries and non-caries. Samples are children aged 3-5 years with a history of consuming bottle milk. The number of samples was 28 people for each group (caries and non-caries) so that the total sample was 56 people. Samples were taken from saliva conservatively carried out in the morning around 8.00-10.00 with the aim as time to queue. At that time, it is expected that the state of the mouth is clean because the child has eaten breakfast and has not had lunch.

\section{Saliva sampling}

Samples were taken from saliva and plaque conservatively conducted in the morning around 8.00-10.00 with the aim as an intermediate time. At that time, it is expected that the state of the mouth is clean because the child has eaten breakfast and has not had lunch. Plaque collection is done using a sterile Copan swab, in the form of a long cotton bud, to avoid the child's fear of plaque collection. Besides Copan was chosen because it is guaranteed sterilization as long as the Copen stalk is not touched and its application is very easy. The assessment of caries determination is based on the WHO deft criteria.

\section{Measurement of CD14 by ELISA}

All reagents were prepared and samples were placed at room temperature before use. Then, $50 \mu \mathrm{L}$ CD14 is added to the standard well. After that, the samples were put into 40 wells for each well and added $10 \mu \mathrm{L}$ of anti-ER antibodies and $50 \mu \mathrm{L}$ of streptavidin-HRP into the sample wells and standard wells. Then, the well is covered with seal and incubated for $60 \mathrm{~min}$ at $37^{\circ} \mathrm{C}$. After that, wash the well 5 times using wash buffer. Then, $50 \mu \mathrm{L}$ of substrate $A$ solution was added to each well and incubated again for $10 \mathrm{~min}$ at $37^{\circ} \mathrm{C}$ in a dark room. Next, $50 \mu \mathrm{L}$ stop solution is added to all the wells and measure the absorbance value using a wavelength of $450 \mathrm{~nm}$ (product by Bioassay Technology Laboratory, Shanghai, China).

\section{Measurement of sIgA by ELISA}

All reagents were prepared and samples were placed at room temperature before use. Then, the saliva sample is diluted at a ratio of $1: 5$ in the saliva thinner. After that, transfer the sample, control and standard into a $1.5 \mathrm{~mL}$ sterile tube and add $4 \mathrm{~mL}$ of $\mathrm{s} \lg \mathrm{A}$ diluent into each tube. Next, add $50 \mu \mathrm{L}$ of the enzyme conjugate antibody into each tube. Then, incubate for 90 min at room temperature. Subsequently, samples and controls and standards were transferred into the well and incubated again for 90 min while in the incubator at $400 \mathrm{rpm}$. After that, all wells are washed 6 times using wash buffer. Subsequently, $50 \mu \mathrm{L}$ TMB substrate was added to each well. Leave 5 min on the shaker incubator and incubate for $40 \mathrm{~min}$ in a dark room. Next, add $50 \mu \mathrm{L}$ stop solution and stir for $3 \mathrm{~min}$. Then, the absorbance is measured with a wavelength of $450 \mathrm{~nm}$ (product by Salimetrics, LLC, USA).

\section{Statistical analysis}

Data are presented in mean and elementary forms. The statistical analysis used is SPSS 16.0. The statistical test used is an independent t-test. $p<0.05$ was said to be statistically significant.

\section{Results}

Table 1 shows that the difference between caries and non-caries from CD14 (Figure 1).

Table 1: Differences in mean levels of CD14 by group

\begin{tabular}{ll}
\hline Group & CD14 levels $(\mathrm{ng} / \mathrm{ml})($ Mean \pm SD) \\
\hline Caries & $0.60 \pm 0.03$ \\
Non-caries & $0.59 \pm 0.24$ \\
\hline
\end{tabular}


Table 2 shows the difference between caries and non-caries from IgA (Figure 2).

Table 2: Differences in mean levels of IgA by group

\begin{tabular}{ll}
\hline Group & IgA levels $(\mathrm{ng} / \mathrm{ml})($ Mean $\pm \mathrm{SD})$ \\
\hline Caries & $1.04 \pm 47.35$ \\
Non-caries & $80.62 \pm 22.08$ \\
\hline
\end{tabular}

\section{Discussion}

The pathogenesis of caries involves the role of dental plaque that begins with adhesion of salivary proteins to the tooth surface and is followed by bacterial colonization. These bacteria convert sugar into energy which causes an acidic environment in the oral cavity

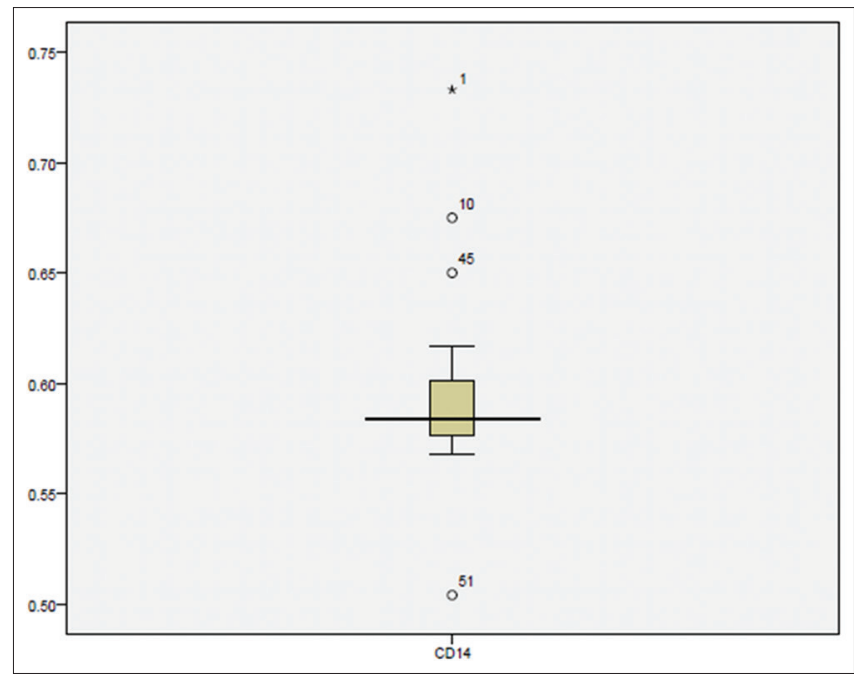

Figure 1: Boxplot graph of CD14 levels

resulting in demineralization of tooth enamel and cause dental caries. Saliva plays a role in the pathogenesis of caries, namely, in the process of formation of S. mutans colonies. Saliva plays a role as a defense system against bacterial infections and maintains a balance between demineralization and remineralization [19].

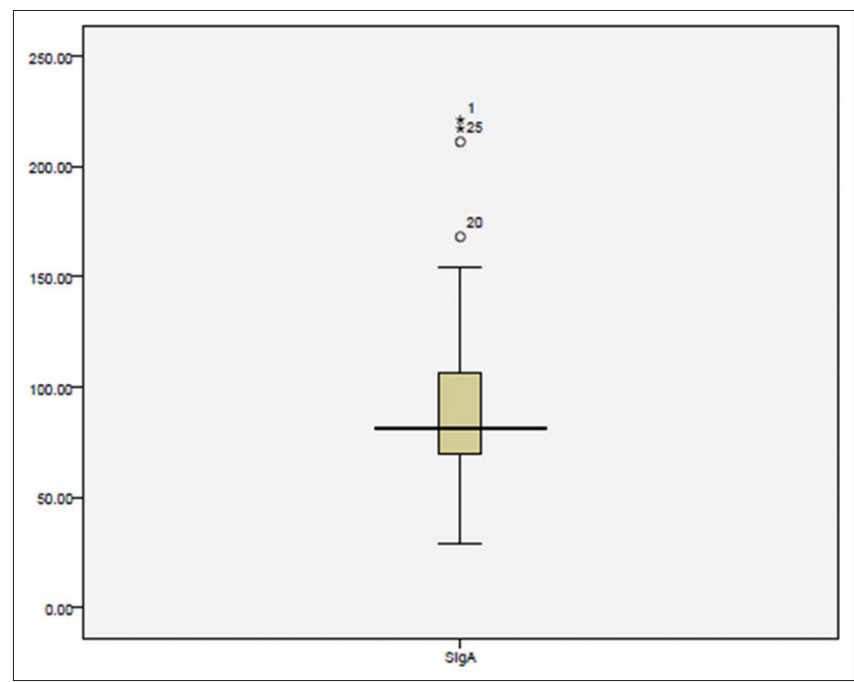

Figure 2: Boxplot graph of IgA levels
Hence, it cannot use other fluids for dental caries problems in this study.

Dental caries is a term that describes a signs, symptoms, and side effects due to chemical imbalance from the tooth surface (enamel and dentin) caused by dental plaque and mediated by saliva [20]. The etiology of ECC is not much different from caries in permanent teeth, but the intake foods or drinks that are high in sugar are one of the strong factors against ECC [21].

Saliva plays a role in maintaining oral health and homeostasis because it has immunological and non-immunological content [16], [17]. Every change in salivary protein composition plays an important role in the etiology of oral disease and development of dental caries [17]. The immune system in children develops with age and becomes more sensitive to various microbiota and different antigens [16].

sCD14 is a glycoprotein that functions in lipopolysaccharides (LPS)/cell wall product signaling by controlling the level of the immune system response [17]. Low levels of sCD14 because specific immune responses are still not fully developed in children aged 3-5 years, an increase in SCD14 levels in saliva may be a response of the immune system which are reparative to inadequate immunoglobulins such as $\lg A$ and lgG [22].

Differences in SCD14 levels in the ECC and caries-free groups indicate the role of the innate immune system in the oral cavity. sCD14 plays an important role in the initiation of the immune response by recognizing several microbial products, such as LPS, endotoxins, and peptidoglycan, which are the main components of Grampositive and Gram-negative bacteria [16]. SCD14 levels can be used as caries biomarkers and help in monitoring or evaluating effectiveness of karyostatic treatment [23].

CD14 is present on the surface of monocytes, macrophages, and neutrophils, through the glycosylphosphatidylinositol anchor, and is present in the soluble form plasma, sCD14. The main salivary gland secretes sCD14 into saliva. SCD14 acts as an important anti-cariogenic factor. This allows binding between epithelial cells and bacteria and activates the production of cytokines for phagocyte recruitment. This protein mediates activation of endothelial and epithelial cells, which are CD14-negative cells [24].

$\operatorname{sig} A$ is the protein most commonly found in saliva. Antibodies in saliva are the first line in the immune system to fight antigens [25]. Salivary IgA secretions are believed to be factors that protect dental caries by controlling the growth of cariogenic oral microflora, preventing pathogenic adhesion, and activation of enzymes and toxins from bacteria [26]. Increased levels of slgA in caries patients are an immune system response as a protective mechanism against the process of dental caries and $S$. mutans are active in the oral cavity [18].

Neutrophils in saliva are the first defense cells against pathogenic microbes. Neutrophils can 
recognize surface bound or free molecules secreted by bacteria including $S$. mutans such as peptidoglycan, lipoprotein, lipoteichoic acid, LPS, CpG-containing DNA, and flagellin [23]. Neutrophils in the area of infection bind and swallow microbes through a process which is called phagocytosis. Interleukin-8 is a type of cytokine that acts as a mediator in the migration of neutrophils to sites of inflammation and infection [27].

Two main classes of antibodies present in saliva, namely, $\lg A(\operatorname{sg} A)$ and $\lg G$, are produced as IgA dimmers by local plasma cells in the salivary gland stroma. Then, these antibodies are carried by the epithelium and are secreted by the polymeric immunoglobulin receptor which is also called a secretory membrane component. IgA polymers are produced by plasma cells in the lamina propria of the oral mucosa. IgA polymers bind to immunoglobulin receptors on the surface of epithelial cells, then by endocytosis, the complex IgA receptor passes through the cellular compartment before being released to the surface of epithelial cells. Then, there is proteolysis of the receptor, and the dimmer $\lg \mathrm{A}$ molecule and free secretory components spread throughout the mucosa including the saliva [28], [29].

\section{Conclusion}

This study concluded that early caries childhood caries event children age 3-5 years increased the levels of $\lg A$ and decreased CD14 levels.

\section{References}

1. Anil S, Anand PS. Early childhood caries: Prevalence, risk factors, and prevention. Front Pediatr. 2017;5:157. https://doi. org/10.3389/fped.2017.00157

PMid:28770188

2. Martins LG, Pereira KC, Costa SX, Traebert E, Lunardelli SE, Lunardelli $\mathrm{AN}$, et al. Impact of dental caries on quality of life of school children. Braz Res Pediatr Dent Integr Clin. 2016;16(1):307-12. https://doi.org/10.4034/pboci.2016.161.32

3. American Academy of Pediatric Dentistry. Policy on Early Childhood Caries (ECC): Classifications, Consequences, and Preventive Strategies Reference Manual. Vol. 40. Chicago, Illinois: American Academy of Pediatric Dentistry; 2016. p. 60-2.

4. World Health Organization. WHO Expert Consultation on Public Health Intervention against Early Childhood Caries: Report of a Meeting, Bangkok, Thailand. Geneva: World Health Organization; 2017.

5. Elidrissi SM, Naidoo S. Prevalence of dental caries and toothbrushing habits among preschool children in Khartoum State, Sudan. Int Dent J. 2016;66(4):215-20. https://doi. org/10.1111/idj.12223

PMid:27061284
6. Kakanur M, Nayak M, Patil SS, Thakur R, Paul ST, Tewathia N. Exploring the multitude of risk factors associated with early childhood caries. Indian J Dent Res. 2017;28(1):27-32. https:// doi.org/10.4103/ijdr.ijdr_35_16

PMid:28393814

7. Chen KJ, Gao SS, Duangthip D, Lo EC. Prevalence of early childhood caries among 5-year-old children: A systematic review. J Investig Clin Dent. 2019;10(1):e12376. https://doi. org/10.1111/jicd.12376

PMid:30499181

8. Meyer F, Enax J. Early childhood caries: Epidemiology, aetiology, and prevention. Int J Dent. 2018;5:1-7. https://doi. org/10.1155/2018/1415873

PMid:29951094

9. Kementerian Kesehatan Republik Indonesia. Riset Kesehatan Dasar (Riskesdas). Jakarta: Kementerian Kesehatan Republik Indonesia; 2013.

10. Setiawati F, Sutadi H, Rahardjo A. Relationship between breastfeeding status and early childhood caries prevalence in 6-24 months old children in Jakarta. J Int Dent Med Res. 2017;10(2):308-12

11. Widita E, Pamardiningsih $Y$, Vega CA. Caries risk profiles amongst preschool aged children living in the Sleman district of Yogyakarta, Indonesia. J Dent Indones. 2017;24(1):1-6. https:// doi.org/10.14693/jdi.v24i1.994

12. Patidar D, Sogi S, Singh V, Shinu P, Loomba A, Patidar DC Salivary levels of Streptococcus mutans and Streptococcus sanguinis in early childhood caries: An in vivo study. J Indian Soc Pedod Prev Dent. 2018;36(4):386-90. https://doi.org/10.4103/ jisppd.jisppd_204_18 PMid:30324930

13. Ghaitsa G, Widodo W, Adhani R. Perbandingan indeks karies antara anak yang mengkonsumsi susu botol dengan tanpa botol usia 2-5 tahun. Dentino (J Kedok Gigi). 2017;2(2):205-10.

14. Buhari N, Abidin FN, Mani SA, Khan IM. Oral Hygiene Practices and Bottle Feeding Pattern among Children with Early Childhood Caries: A Preliminary Study. Malaysia: University of Malaya; 2016.

15. Hemadi AS, Huijie R, Zhou Y, Zou J. Salivary proteins and microbiota as biomarkers for early. Int J Oral Sci. 2017;9(11):e1. https://doi.org/10.1038/ijos.2017.35

PMid:29125139

16. Kumar S, Tandon S, Nayak R, Saran R, Pentapati KC Relationship of salivary CD14 concentration with dental caries in young children. J Clin Exp Dent. 2017;9(8):e958-61. https:// doi.org/10.4317/jced.53796 PMid:28936284

17. Nishana E, Bhat SS, Sahana KS, Hegde SK, Bhat V, Kalal BS Estimation of salivary SCD14 in children with early childhood caries in association with pneumonia. Rep Biochem Mol Biol. 2019;8(2):132-38.

PMid:31832436

18. Haeri-Araghi H, Zarabadipour M, Safarzadeh-Khosroshahi S, Mirzadeh M. Evaluating the relationship between dental caries number and salivary level of IgA in adults. J Clin Exp Dent. 2018;10(1):e66-9. https://doi.org/10.4317/jced.54271 PMid:29670718

19. Chrismirina $S$, Agoeng $T$, Soenarso B. Microbial biofilm formation in the oral cavity. Indones J Dent. 2006;13(1):55-60.

20. Alazmah A. Early childhood caries: A review. J Contemp Dent Pract. 2017;18(8):732-7. https://doi.org/10.5005/ jp-journals-10024-2116 PMid:28816199

21. Musa HT, Zwain AM, Al-Mizraqchi AS. Salivary immunoglobulin $a$ in relation to the viable count of mutans streptococci in children 
with early childhood caries. Int J Sci Res. 2017;6(7):1709-13. https://doi.org/10.21275/art20175608

22. Sruthi KS, Yashoda R, Puranik MP. Diagnostic potential of saliva as a biomarker in early childhood caries: A review. Int $\mathrm{J}$ Appl Dent Sci. 2019;5(2):341-7.

23. Astuti ES, Sukrama IM, Mahendra AN. Innate immunity signatures of early childhood caries (ECC) and severe early childhood caries (S-ECC). Biomed Pharmacol J. 2019;12(3):1129-34. https://doi.org/10.13005/bpj/1740

24. Ghigo D, Bergandi L. Use of the Salivary Protein CD14 as an Indicator of the Low Risk to Developing Dental Caries. United States: United States Patent Application Publication; 2008.

25. Bansode PV, Pathak SD, Wavdhane MB, Birage PP. Salivary biomarkers of dental caries a review article. IOSR J Dent Med Sci. 2019;18(1):52-8.

26. Laputková G, Schwartzová V, Bánovčin J, Alexovič M, Sabo J.
Salivary protein roles in oral health and as predictors of caries risk. Open Life Sci. 2018;13:174-200. https://doi.org/10.1515/ biol-2018-0023

27. Luthfi M, Indrawati R, Dachlan YP. Korelasi jumlah Streptococcus mutans (S. mutans) dan level ekspresi interlukin 8 (IL-8) pada severe early childhood caries. Majalah Kedok Gigi Indones. 2015;1(2):142-8. https://doi.org/10.22146/majkedgiind.9227

28. Brandtzaeg P. Secretory IgA: Designed for anti-microbia defense. Front Immunol. 2013;4:222. https://doi.org/10.3389/ fimmu.2013.00222

PMid:23964273

29. Hamuro K, Kotani Y, Toba M, Kakumoto K, Kohida N. Comparison of salivary IgA secretion rate collected by the aspiration method and swab method. Biosci Microbiota Food Health. 2013;32(3):107-12. https://doi.org/10.12938/bmfh.32.107 PMid:24936369 